\title{
Analisis Pengaruh Sumber Daya Manusia, Infrastruktur Ekonomi Dan Social Capital Terhadap Pertumbuhan Ekonomi Di Kabupaten Lampung Timur
}

\author{
Ahmad Mustofa ${ }^{1}$ Dede $^{2}$ \\ STIE Lampung Timur \\ ekaparianti@gmail.com
}

\begin{abstract}
Abstrak
Tujuan penelitian ini adalah menganalisis pengaruh sumber daya manusia, infrastruktur ekonomi, dan social capital terhadap pertumbuhan ekonomi di Kabupaten Lampung Timur. Data yang digunakan dalam penelitian ini 2008-2017 dari 24 wilayah kecamatan di Kabupaten Lampung Timur. Metode yang digunakan menggunakan Analisis Panel Data. Hasil penelitian ini mendapati bahwa terdapat pengaruh antara jumlah usia produktif, infrastruktur jalan dan konsumsi listrik sedangkan untuk jumlah lulusan SLTA dan konsumsi air bersih penduduk tidak mempunyai pengaruh dengan pertumbuhan ekonomi di Lampung Timur. Hasil penelitian ini dapat menjadi masukan bagi Pemerintah Daerah (Pemda) untuk membantu dalam pengambilan keputusan dalam meningkatkan perekonomian masyarakat di Kabupaten Lampung Timur. Optimalisasi SDM dan usaha meningkatkan infrastuktur serta pemberdayaan social capital mampu meningkatkan pertumbuhan ekonomi daerah, sehingga akan mempengaruhi efesiensi dan kelancaran kegiatan ekonomi pada sektor lain
\end{abstract}

Kata kunci: Sumber Daya Manusia, Infrastruktur, Social Capital, Pertumbuhan Ekonomi

\section{Pendahuluan}

Salah satu faktor utama keberhasilan pembangunan di suatu negara adalah tersedianya kecukupan sumber daya manusia (SDM) yang berkualitas. Alokasi sumber daya manusia yang efektif adalah pemula pertumbuhan ekonomi. Serta ekonomi tumbuh, akumulasi modal (fisik) baru mulai dibutuhkan untuk menjaga agar ekonomi tumbuh. Dengan kata lain alokasi sumber daya manusia yang efektif merupakan syarat perlu (Necessary Condition) bagi pertumbuhan ekonomi. (Lonni et al, 2008).

Kabupaten Lampung Timur terlatak di bagian Timur Provinsi Lampung. Kabupaten Lampung Timur terbagi kedalam 24 wilayah adminstrtrative Kecamatan. Setiap kecamatan pada kabupaten ini rata-rata masing-masing kecamatan terbagi menjadi 11 wilayah administrative desa. Populasi penduduk di kabupaten Lampung Timur rmengalami peningkatan setiap tahunnya. Berikut ini adalah grafik data jumpal penduduk di kabupaten Lampung Timur:

\footnotetext{
${ }^{1}$ Korespondensi: Ahmad Mustofa. STIE Lampung Timur, Jl pramuka, Labuhan Ratu 1, Way Jepara Lampung Timur. ekaparianti@gmail.com

${ }^{2}$ Korespondensi: Dede. STIE Lampung Timur, Jl pramuka, Labuhan Ratu 1, Way Jepara Lampung Timur. tofafandi@gmail.com
} 


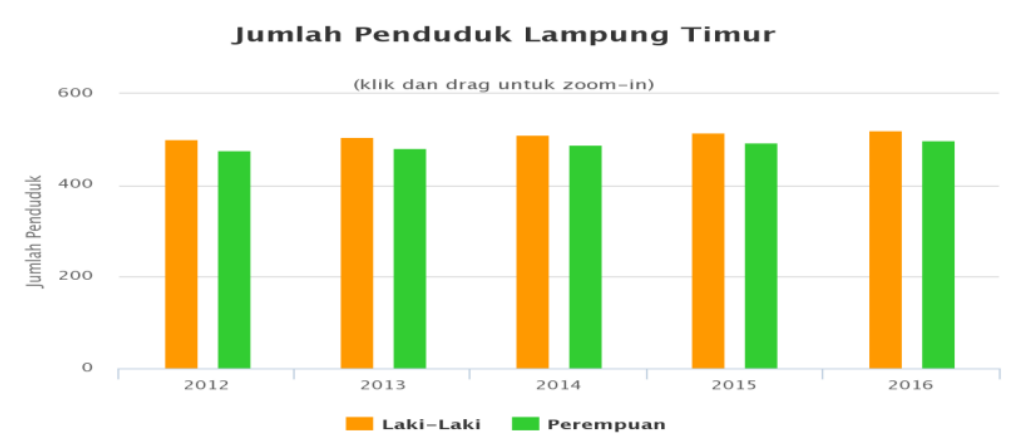

Sumber: BPS Statistik Kabupaten Lampung Timur 2016

Gambar 1. Jumlah Penduduk Kabupaten Lampung Timur dan komposisi jumlah penduduk lakilaki dan permepuan tahun 2012-2016

Gambar 1 diatas menunjukkan setiap tahunnya jumlah penduduk di kabupaten Lampung Timur mengalami peningkatan. Apabila ditinjau dari komposisi jumlah laki-laki dan perempuan, maka terlihat bahwa jumlah laki-laki lebih banyak dibandingkan dengan perempuan. Peningkatan jumlah penduduk ini ternyata belum didukung oleh SDM yang berkualitas. Sehingga perlu adanya peningkatan dan pengembangan SDM di kabupaten Lampung Timur. Pengembangan Sumber Daya Manusia (SDM) yang telah menjadi fokus perhatian dalam pembangunan di Kabupaten Lampung Timur selama ini sangat relevan dengan upaya peningkatan kualitas SDM Kabupaten Lampung Timur yang dipandang relatif rendah. Mulyadi (2008) menjelaskan bahwa ada empat kebijaksanaan pokok dalam upaya peningkatan sumber daya manusia yaitu Peningkatan kualitas SDM yang produktif, Peningkatan kualitas SDM berkemampuan dalam pemanfaatan, mengembangkan dan menguasai iptek yang berwawasan lingkungan, Pengembangan pranata yang meliputi kelembagaan dan perangkat hukum yang mendukung upaya peningkatan kualitas SDM, Dalam modal pembangunan manusia terdapat keterkaitan antar pembangunan ekonomi dan pembangunan sumber daya manusia. Peningkatan SDM sekarang ini lebih difokuskan kepada pemberian kesempatan seluas-luasnya kepada penduduk untuk mengecap pendidikan, terutama penduduk kelompok usia sekolah (umur 7-24 tahun).

Hasil Susenas BPS Kabupaten Lampung Timur 2015 menunjukkan bahwa penduduk yang masih bersekolah pada kelompok umur 7-12 tahun mempunyai persentase paling tinggi. Jika dilihat angka partisipasi murni tertinggi adalah SD/MI yaitu sebesar 99,01\%. Sedangkan untuk tingkat SMP/Mts 84,76, Sedangkan tingkat SMA/ SMK/MA hanya 59,85\%. Hal ini menunjukkan bahwa masih sangat terbatasnya fasilitas pendidikan yang menyebabkan angka pendidikan di level Menengah pertama dan atas masih sangat kecil di kabupaten Lampung Timur.Jika ditinjau dari struktur perekonomian di Kabupaten Lampung Timur, perekonomian didominasi oleh tiga sektor utama yaitu sektor pertanian, pertambangan dan penggalian, perdagangan, hotel, dan restoran. Adapun dalam kurun waktu lima tahun terakhir, tidak terjadi perubahan struktur perekonomian yang signifikan di Kabupaten Lampung Timur, namun PDRB mengalami peningkatan yang cukup signifikan dari tahun ketahun. Berikut ini tabel PDRB kabupaten Lampung Timur tahun 2011-2015: 
eCo-Buss

Tabel 1. PDRB Kabupaten Lampung Timur (2011-2015)

\begin{tabular}{|c|c|c|c|c|c|}
\hline \multirow{2}{*}{ PDRB } & \multicolumn{5}{|c|}{ PDRB Kabupaten Lampung Timur (Juta Rupiah) } \\
\hline & 2011 & 2012 & 2013 & 2014 & 2015 \\
\hline $\begin{array}{l}\quad \text { Produk } \\
\text { Domestik } \\
\text { Regional Bruto }\end{array}$ & $\begin{array}{r}21.891 .63 \\
4.2\end{array}$ & $\begin{array}{r}23.704 .74 \\
1.2\end{array}$ & $\begin{array}{r}26.769 . \\
080.4\end{array}$ & $\begin{array}{r}29.535 . \\
436.8\end{array}$ & $\begin{array}{r}31.319 .19 \\
0.3\end{array}$ \\
\hline Produk & & & & & \\
\hline Domestik & 15.611 .44 & 17.149 .21 & 18.913. & 21.259. & \\
\hline $\begin{array}{l}\text { Regional Bruto } \\
\text { Tanpa Migas }\end{array}$ & 0.3 & 8.9 & 980.8 & 904.9 & 2.389 .3754 \\
\hline
\end{tabular}

Sektor pertanian merupakan sektor yang memberikan kontribusi terbesar terhadap perekonomian Kabupaten Lampung Timur. Kabupaten Lampung Timur merupakan lumbung padi terbesar kedua di Provinsi Lampung setelah kabupaten Lampung Tengah. (BPS Sttatistik Kabupaten Lampung Timur, 2016). Sub sektor tanaman bahan makanan merupakan sub sektor yang memberikan kontribusi terbesar terhadap sektor pertanian, diikuti sub sektor perikanan dan perkebunan. Apabila dilihat dalam konstelasi ruang Provinsi Lampung, Kabupaten Lampung Timur merupakan satu-satunya kabupaten yang menjadikan sektor pertambangan dan penggalian sebagai sektor basis, terutama dari sub sektor minyak dan gas bumi. Pertumbuhan Ekonomi di kabupaten Lampung Timur mengalami fluktuasi jika ditinjau dari kondisi inflasi. Pada pertengahan tahun 2013 dan tahun 2014 mengalami kenaikan inflasi yang sangat tajam. Berikut ini adalah data inflasi kabupaten Lampung Timur tahun 2013-2015:

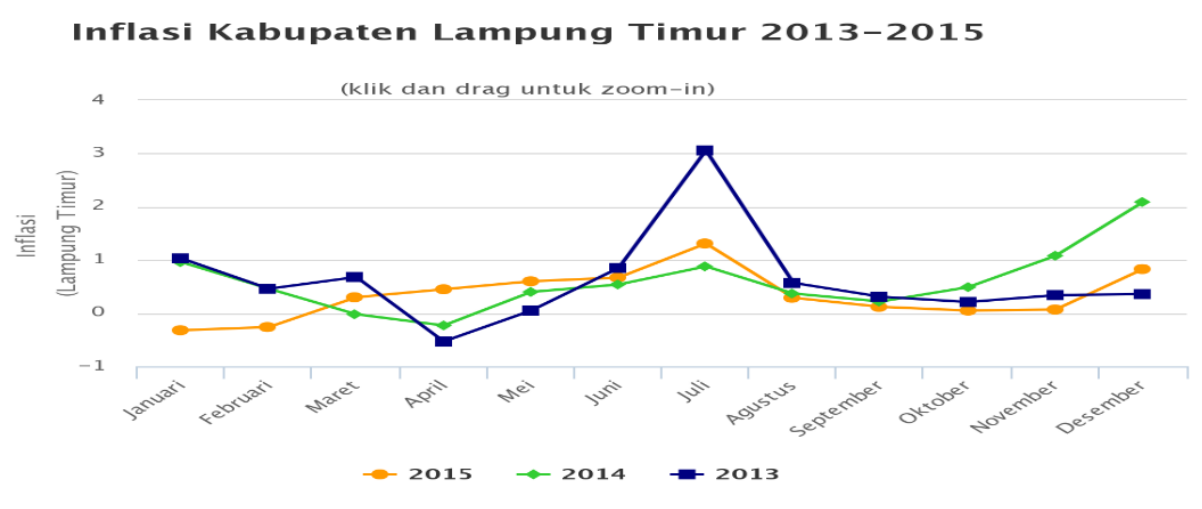

Gambar 2. Inflasi Kabupaten Lampung Timur tahun 2015-2015

Dari data Inflasi diatas menunjukkan bahwa kondisi pertumbuhan ekonomi di Kabupaten Lampung Timur masih mengalami fluktuatif. Pada 3 tahun terakhir kondisi inflasi sangat mempengaruhi kondisi perekonomian di kabupaten Lampung Timur. Dan kondisi yang ada juga belum didukung adanya kualitas SDM yang baik dan adanya infrastuktur ekonomi yang dapat mendukung perekonomian. Sehingga penelitian ini sangat penting dilakukan untuk menguji dan menganalisis pengaruh SDM dan Infrastruktur ekonomi yang ada di Kabupaten Lampung Timur terhadap kondisi perekonomian. Fahlevi dan Gunawan (2016) melakukan penelitian bagaimana 
pengaruh infrasruktur ekonomi dan social capital terhadap PDRB di 20 kabupaten/kota Provinsi Aceh. Penelitian ini memperoleh bukti bahwa Infrastruktur jalan dan air bersih berpengaruh secara signifikan terhadap PDRB dan Infrastruktur listrik dan koperasi tidak berpengaruh secara signifikan terhadap PDRB di Provinsi Aceh.

Tujuan penelitian ini adalah menganalisis pengaruh sumber daya manusia, infrastruktur ekonomi, dan social capital terhadap pertumbuhan ekonomi di Kabupaten Lampung Timur. Hasil penelitian ini diharapkan dapat menjadi masukan bagi pembuat kebijakan (policy making) khususnya Pemerintah Daerah Kabupaten Lampung Timur dalam upaya meningkatkan perekonomian masyarakat dan mengoptimalisasikan SDM yang masih rendah, dan meningkatkan infrastuktur ekonomi dan adanya social capital yang dapat meningkatkan pertumbuhan ekonomi.

\section{Landasan Pustaka}

Lonni et.al (2016) memyatakan bahwa pertumbuhan ekonomi dapat diartikan juga sebagai proses kenaikan kapasitas produksi suatu perekonomian yang diwujudkan dalam bentuk kenaikan pendapatan nasional. Adanya pertumbuhan ekonomi merupakan indikasi keberhasilan pembangunan ekonomi. Produk Domestik Regional Bruto (PDRB) adalah salah satu indikator makro yang digunakan untuk mengukur keberhasilan proses pembangunan. Menurut Siberani (2002) Produk Domestik Regional Bruto adalah nilai tambah yang mampu diciptakan berbagai aktivitas ekonomi dalam suatu wilayah. Pembangunan manusia juga akan mempengaruhi pertumbuhan ekonomi, karena tanpa pembangunan manusia yang berkelanjutan tidak akan dapat dicapai pembangunan ekonomi yang cukup memadai. Namun keterkaitan tersebut secara empiris tidak bersifat otomatis. Artinya lebih banyak daerah yang mengalami pertumbuhan ekonomi yang cepat tanpa diikuti oleh pembangunan manusia yang seimbang, (Adisasmita, 2008).

Pranessy (2012) menjelaskan bahwa infrastruktur merupakan input penting bagi kegiatan produksi dan dapat mempengaruhi kegiatan ekonomi dalam berbagi cara baik secara langsung maupun tidak langsung. Infrastruktur tidak hanya merupakan kegiatan produksi yang akan menciptakan output dan kesempatan kerja, namun keberadaan infrastruktur juga mempengaruhi efesiensi dan kelancaran kegiatan ekonomi disektor-sektor lainnya. Infrastruktur sebagai fasilitas fisik yang dikembangkan atau dibutuhkan oleh agen-agen publik untuk fungsifungsi pemerintahan dalam penyediaan air, tenaga listrik, pembuangan limbah, transportasi dan pelayanan-pelayanan lainnya untuk memfasilitasi tujuan-tujuan ekonomi dan sosial. Sedangkan untuk social capital, Fahlevi \& Gunawan (2016) menyatakan bahwa Infrastruktur Koperasi adalah termasuk kedalam social capital. Koperasi berkenaan dengan manusia sebagai individu dan dengan kehidupannya dalam masyarakat. Manusia tidak dapat melakukan kerja sama sebagai satu unit, dia memerlukan orang lain dalam suatu kerangka kerja sosial. Berdasarkan uraian diatas maka hipoesis yang diajukan adalah:

H1: Sumber Daya Manusia berpengaruh signifikan terhadap pertumbuhan Ekonomi di Kabupaten Lampung Timur

H2: Infrastruktur Ekonomoi berpengaruh signifikan terhadap pertumbuhan Ekonomi di Kabupaten Lampung Timur

H3: $\quad$ Social Capital berpengaruh signifikan terhadap pertumbuhan Ekonomi di Kabupaten Lampung Timur.

\section{Metode Penelitian}

\section{Sumber Data}

Sumber Data yang dipergunakan dalam penelitian ini adalah data sekunder yang telah dipublikasikan oleh instansi atau lembaga yang terkait dengan topik penelitian ini. Data 
sekunder yang berupa data kuantitatif, terdiri dari data yang diinformasikan atau dimuat dalam dokumen, terbitan ataupun publikasi tahun 2008-2017 (10 tahun) dari 24 wilayah kecamatan di Kabupaten Lampung Timur, khusus yang berisikan: (1) Pertumbuhan Ekonomi (PDRB), (2) Pendidikan, (3) Kesehatan, (4) Penduduk Usia Produktif dari Tahun 2008-2017. jumlah panjang jalan kondisi baik di kabupaten Lampung Timur, (5) jumlah produksi listrik di Kabupaten Lampung Timur, (6) Jumlah kapasitas air bersih yang tercatat oleh Perusahaan Daerah Air Minum (PDAM) (7) jumlah koperasi aktif yang ada di kabupaten Lampung Timur.

2. Definisi Operasional Variabel:

Tabel 2. Definisi Operasional Variabel

\begin{tabular}{|c|c|}
\hline Variabel & Definisi Operasional \\
\hline $\begin{array}{l}\text { Dependent: } \\
\text { Y = Pertumbuhan Ekonomi }\end{array}$ & $\begin{array}{l}\text { Jumlah PDRB (Pendapatan Daerah Regional } \\
\text { Bruto) non migas atas dasar harga konstan. } \\
2000 \text { di kabupaten/kota di Lampung Timur } \\
\text { tahun 2007-2016, dalam satuan (Juta Rupiah). }\end{array}$ \\
\hline $\begin{array}{l}\text { SUMBER DAYA MANUSIA } \\
\text { X1 = Penduduk Usia Produktif } \\
\text { X2= Penduduk Tamat SLTA keatas }\end{array}$ & $\begin{array}{l}\text { Jumlah penduduk di usia produktif } \\
\text { Jumlah penududk yang telah menyelesaikan } \\
\text { sekolah tingkat SLTA }\end{array}$ \\
\hline \multicolumn{2}{|l|}{ INFRASTRUKTUR EKONOMI } \\
\hline X3 = Variabel Jalan & $\begin{array}{l}\text { Jumlah panjang jalan kondisi dalam satuan } \\
(\mathrm{Km}) \text {. }\end{array}$ \\
\hline X4 = Variabel Listrik & $\begin{array}{l}\text { Jumlah produksi listrik yang dihasilkan oleh } \\
\text { konsumen pengguna jasa listrik baik rumah } \\
\text { tangga, badan sosial, badan pemerintah, } \\
\text { industri dan sebagainya, yang tercatat oleh } \\
\text { Perusahaan Listrik Negara (PLN) dalam satuan } \\
\text { (Kwh). } 4\end{array}$ \\
\hline X5 $=$ Variabel Air Bersih & $\begin{array}{l}\text { Jumlah kapasitas air bersih yang disalurkan } \\
\text { kepada pelanggan di kabupaten Lampung } \\
\text { Timur yang tercatat oleh Perusahaan Daerah } \\
\text { Air Minum (PDAM) dalam satuan }\left(\mathrm{M}^{3}\right) \text {. }\end{array}$ \\
\hline \multicolumn{2}{|l|}{ SOCIAL CAPITAL } \\
\hline X6 $=$ Social capital & $\begin{array}{l}\text { Jumlah koperasi aktif yang ada di kabupaten } \\
\text { Lampung Timur. }\end{array}$ \\
\hline
\end{tabular}

3. Model Persamaan Regresi

Penelitian ini menggunakan persamaan berikut untuk menguji hipotesis 1, 2 dan hipotesis 3: $P D R B_{i, t}=\alpha_{0}+\alpha_{1} U P+\alpha_{2} P T S+\alpha_{3} J L N+\alpha_{4} L S T R+\alpha_{5} A B+\alpha_{6} S C+\varepsilon$ 


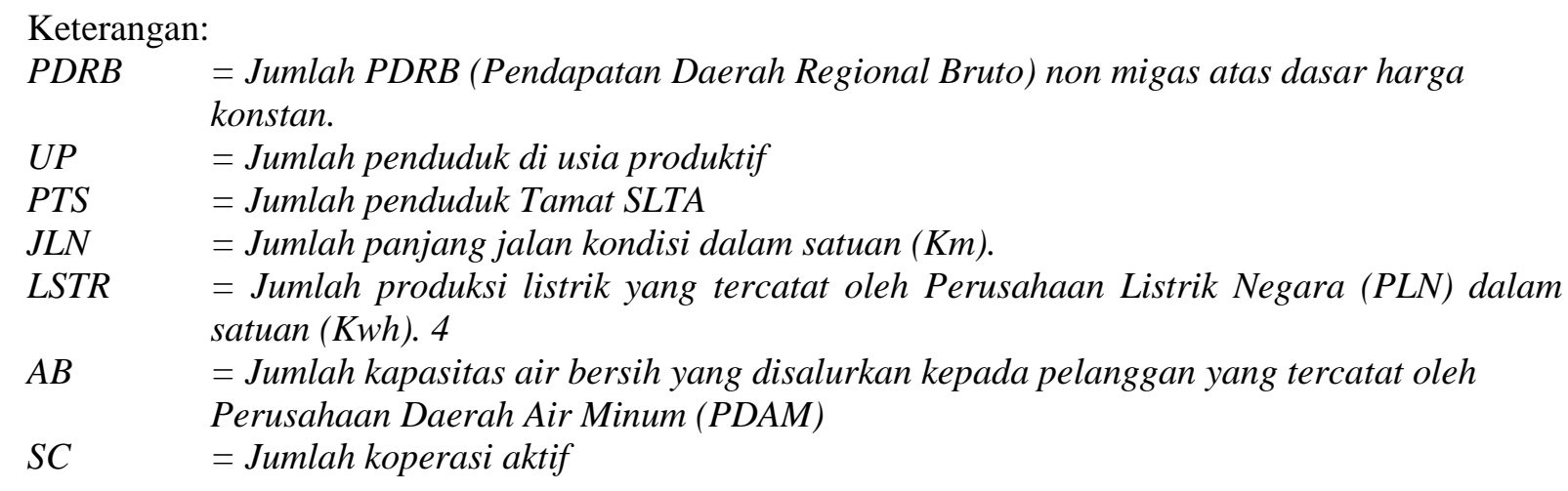

\section{Teknik Analisis Data}

Dalam penelitian ini, analisis data dilakukan dengan menggunakan model regresi data panel. Data Panel atau kumpulan data adalah kombinasi dari deret waktu dan data cross-sectional. Regresi panel dapat mengakomodasi informasi yang terkait dengan variabel baik secara cross-section maupun time series dan secara substansial menurunkan masalah variabel yang comitted, model mengabaikan variabel yang tidak relevan (Frankl, 2005). Metode regresi panel lebih tepat untuk mengatasi interkorelasi antar variabel bebas yang pada akhirnya dapat menyebabkan penilaian model regresi secara tidak akurat (Griffiths, 2001).

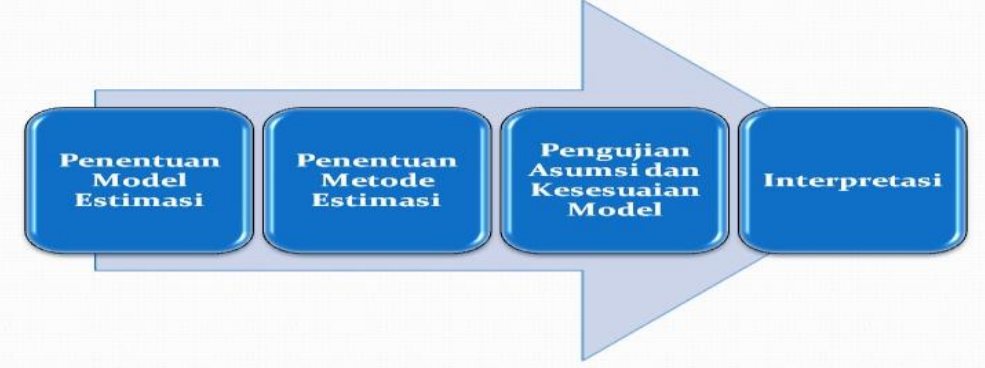

Gambar 3. Tahapan Analsis Panel Data

Tahapan Analisis menggunakan Panel Data: Tahapan Pertama, Penentuan Model Estimasi. Terdapat tiga medel data panel yaitu pendekatan Pooled Least Square model atau PLS dan dikenal pula dengan pendekatan common effect model, pendekatan efek tetap, (fixed effect model), dan pendekatan efek acak (random effect model). Tahapan Kedua, Penentuan Metode Estimasi. Selanjutnya untuk pemilihan model yang tepat yang akan digunakan dalam mengestimasi model regresi dengan menggunakan data panel, dilakukan dengan membandingkan hasil regresi ketiga metode tersebut. Penelitian ini menguji model regresi dengan uji Chow dan Hausmant. Tahapan Ketiga, Pengujian Asumsi dan Kesesuaian Model. Pengujian Asumsi Klasik Model regresi dikatakan sebagai model empiris yang baik jika memenuhi sejumlah asumsi klasik. Asumsi klasik tes model regresi meliputi: 1) Pengujian Normalitas, 2) Pengujian Mutikolinearitas, 3) Pengujian Heteroskedastis, 4) Pengujian Autokorelasi (Ghozali, 2013)

\section{Hasil}

\section{Pengumpulan Data}

Kabupaten Lampung Timur. Data kecamatan di kabupaten Lampung Timur yaitu sebanyak 24 kecamatan. Berikut ini data Kabupaten Lampung Tinur yang terdiri dari beberapa kecamatan: 
Tabel 3. Kecamatan kabupaten Lampung Timur

\begin{tabular}{|l|l|}
\hline No & Kecamatan / District \\
\hline 1 & Metro Kibang \\
\hline 2 & Batang Hari \\
\hline 3 & Sekampung \\
\hline 4 & Marga Tiga \\
\hline 5 & Sekampung Udik \\
\hline 6 & Jabung \\
\hline 7 & Pasir Sakti \\
\hline 8 & Waway Karya \\
\hline 9 & Marga Sekampung \\
\hline 10 & Labuhan Maringgai \\
\hline 11 & Mataram Baru \\
\hline 12 & Bandar Sribhawono \\
\hline 13 & Melinting \\
\hline 14 & Gunung Pelindung \\
\hline 15 & Way Jepara \\
\hline 16 & Braja Selebah \\
\hline 17 & Labuhan Ratu \\
\hline 18 & Sukadana \\
\hline 19 & Bumi Agung \\
\hline 20 & Batanghari Nuban \\
\hline 21 & Pekalongan \\
\hline 22 & Raman Utara \\
\hline 23 & Purbolinggo \\
\hline 24 & Way Bungur \\
\hline
\end{tabular}

\section{Statistik Deskriptif}

Berikut ini adalah tabel statistik deskriptif data penelitian dari 24 kecamatan kabupaten Lampung Timur selama 10 tahun (2007-2018):

Tabel 4. Statistik Deskriptif

\begin{tabular}{|l|r|r|r|r|r|}
\hline & N & Minimum & Maximum & Mean & \multicolumn{1}{l|}{$\begin{array}{l}\text { Std. } \\
\text { Deviation }\end{array}$} \\
\hline $\begin{array}{l}\text { Jumlah Usia } \\
\text { Produktif }\end{array}$ & 240 & 589311 & 788753 & 699198.00 & 62570.368 \\
\hline Jumlah Tamat SLTA & 240 & 10565 & 19041 & 15102.20 & 3484.416 \\
\hline Jalan & 240 & 1453.7 & 2511.2 & 1835.470 & 383.3586 \\
\hline Listrik & 240 & 128775273 & 477541037 & 303512595.8 & 130131236. \\
& & & & 0 & 85 \\
\hline Air Bersih & 240 & 315215 & 651078 & 510394.90 & 112181.230 \\
\hline Jumlah Koperasi & 240 & 21 & 67 & 42.50 & 16.775 \\
\hline PDRB & 240 & 9852886 & 27356543 & 20576006.60 & 5853875.96 \\
\hline
\end{tabular}




\section{eCo-Buss}

\begin{tabular}{|l|l|l|l|l|l|}
\hline & & & & & 9 \\
\hline Valid N (listwise) & 240 & & & & \\
\hline
\end{tabular}

\section{Hasil uji Koefisien Determinasi (Uji $\mathbf{R}^{2}$ )}

Tabel 5 Koefisien Determinasi (Uji $\mathrm{R}^{2}$ )

\begin{tabular}{|c|c|c|c|}
\hline Model & $\mathbf{R}$ & $\begin{array}{c}\text { R Square } \begin{array}{l}\text { Adjusted R } \\
\text { Square }\end{array} \\
\end{array}$ & $\begin{array}{l}\text { Std. Error of } \\
\text { the Estimate }\end{array}$ \\
\hline 1 & $.782^{\mathrm{a}}$ & .627 & 2.02560 \\
\hline
\end{tabular}

Penelitian menggunakan analisis 3 tahapan panel data. Setelah dilakukan analisis data semua tahapan maka penelitian menggunakan panel data metode fix effect regresi. Dengan menggunkan Panel Data Dummy approach analisis regresi menggunakan SPSS V.20. Tabel diatas menunjukkan hasil uji $\mathrm{R}$ square atau uji koefesien determinasi regresi pertumbuhan ekonomi (PDRB) terhadap Sumber Daya Manusia yaitu Usia Produktif (UP), Penduduk Tamat SLTA (PTS) dan Infrastuktur yaitu infrastruktur jalan (JLN), Infrastuktur Listrik (LSTR), Infrastuktur Air Bersih (AB) serta Social Capital (SC) adalah sebesar 0.627 Hal ini berarti sebesar 62,7 persen variasi tingkat Pertumbuhan Ekonomi dapat dijelaskan oleh variabel independen yaitu sumber daya manusia, infrastuktur ekonomi dan social capital. Sedangkan sisanya sebesar 37,3 persen dipengaruhi oleh faktor-faktor lain atau variabel lain diluar model. Dengan demikian secara umum model yang dipergunakan ini dapat dikatakan baik karena nilai $\mathrm{R}^{2}$ lebih daripada (>0.50), yaitu model menjelaskan pengaruh pertumbuhan ekonomi terhadap sumberdaya manusia, infrastruktur dan social capital.

\section{Uji Regresi Panel Data}

Tabel 6. Hasil Uji Pertumbuhan Ekonomi terhadap Sumber Daya Manusia, Infrastruktur ekonomi, dan Social Capital

\begin{tabular}{llrrrrr}
\multicolumn{8}{c}{ ANOVA $^{\mathrm{a}}$} \\
\hline Model & & $\begin{array}{l}\text { Sum of } \\
\text { Squares }\end{array}$ & df & Mean Square & F & Sig. \\
\hline \multirow{4}{*}{1} & Regression & 16.318 & 12 & 6.938 & 3.050 & $.000^{\mathrm{b}}$ \\
& Residual & 106.702 & 7 & 9.294 & & \\
& Total & 122.020 & 239 & & & \\
\hline
\end{tabular}

Tabel 7. Pengaruh Pertumbuhan Ekonomi terhadap Sumber Daya manusia, Infrastruktur Ekonomi dan Social Capital

Equation: $P D R B_{i, t}=\alpha_{0}+\alpha_{1} U P+\alpha_{2} P T S+\alpha_{3} J L N+\alpha_{4} L S T R+\alpha_{5} A B+\alpha_{6} S C+\varepsilon$

\begin{tabular}{lllll}
\hline Independent Variable & $\begin{array}{l}\text { Expected } \\
\text { Sign }\end{array}$ & Beta & t-value & Sig $(\boldsymbol{p}$-value $)$ \\
\hline Constanta & - & 2.159 & 3.074 & $\mathbf{0 . 0 0 1}$ \\
Usia Produktif $($ UP) & - & 0.104 & 2.321 & $\mathbf{0 . 0 0 0}$ \\
Penduduk Tamat SLTA $(P T S)$ & + & 0.021 & 0.811 & $\mathbf{0 . 0 7 4}$ \\
Infrastruktur Jalan $(J L N)$ & + & 0.212 & 1.859 & $\mathbf{0 . 0 0 4}$ \\
Infrastruktur Listrik $($ LSTR) & + & 0.261 & 2.095 & $\mathbf{0 . 0 0 2}$ \\
Air Bersih $($ AB) & + & 0.025 & 0.062 & $\mathbf{0 . 1 2 6}$ \\
Social Capital $(S C)$ & + & 0.342 & 2.665 & $\mathbf{0 . 0 0 0}$ \\
\hline
\end{tabular}


Tabel diatas menunjukkan bahwa nilai konstanta dari hasil regresi sebesar 2.159 yang berarti tanpa kenaikan sumberdaya manusia (usia produktif dan penduduk tamatan SLTA) dan infrastruktur (jalan, listrik, air bersih) serta social capital (koperasi) maka PDRB kabupaten Lampung Timur sebagai indikator pertumbuhan ekonomi, secara rata-rata hanya mencapai 2,159 persen.

Berdasarkan hasil estimasi regresi berganda data panel menggunakan fix effect method analisis pengaruh PDRB dan sumberdaya manusia, infrastrukturs ekonomi serta social capital diperoleh nilai $\mathrm{p}$-value $=0.00<0.05$, sehingga dapat dikatakan bahwa infrastruktur jalan dan listrik berpengaruh signifikan terhadap PDRB di kabupaten Lampung Timur. Hasil ini konsisten dengan hasil penelitian Lonni et al (2009) dan Fahlevi \& Gunawan (2016)

Hasil yang berbeda didapatkan pada regresi antara PDRB dengan sumberdaya manusia (penduduk tamatan SLTA) dan infrastruktur air bersih di mana diperoleh nilai p-value $0.074>$ 0.05 dan $0.126>0.05$ sehingga dapat dikatakan bahwajumlah penduduk tamatan SLTA dan infrastruktur air bersih tidak berpengaruh signifikan terhadap PDRB di Kabupaten Lampung Timur. Hasil ini memberi bukti empiris bahwa jumlah penduduk tamatan SLTA masih belum mencukupi untuk menggerakkan pertumbuhan ekonomi baik dalam segi kualitas dan kuantitas di Kabupaten Lampung Timur. Dan pemakain air bersih oleh penduduk masih belum mempengaruhi pertumbuhan ekonomi didaerah tersebut. Ketersediaan air bersih juga belum menjadi faktor yang berpengaruh terhadap pertumbuhanekonomi di kabupaten Lampung Timur karena ketersediaan air bersih yang belum dikelola dengan baik oleh pemerintah daerah. Sehingga perlu adanya perhatian dari pemerintah daerah untuk menggerakkan perekonomian dengan penyediaan dan pengelolaan air bersih yang baik.

\section{Simpulan}

Hasil penelitian pengaruh PDRB terhadap sumber daya manusia (usia produktif, dan penduduk tamatan SLTA), infrastruktur ekonomi (listrik, jalan dan air bersih) serta social capital (koperasi) terhadap pertumbuhan ekonomi di Kabupaten Lampung Timur. Hasil estimasi regresi menggunakan Panel Data menunjukkan bahwa usia produktif, infrastruktur jalan, infrastruktur listrik dan koperasi berpengaruh signifikan terhadap PDRB. Oleh karena itu pemerintah daerah harus lebih memperhatikan sumber daya manusia terutama usia produktif. kondisi infrastruktur jalan dan listrik di seluruh daerah kabupaten Lampung Timur. Hal ini karena variabel tersebut dapat mendorong pertumbuhan ekonomi. Sedangkan penduduk tamatan SLTA dan ketersediaan air bersih tidak berpengaruh pada PDRB, karena di Kabupaten Lampung Timur masih sangat kurang dalam kualitas maupun kuantitas lulusan SLTA yang mampu mengerakkan perekonomian daerah..

\section{Daftar Pustaka}

Adisasmita, R., (2008). Pengembangan wilayah: konsep dan teori. Edisi pertama. Yogyakarta, Graha Ilmu.

Arsyad, Lincolin. (1995). Pengantar dan Perencanaan Pembangunan Ekonomi Daerah. Edisi Pertama, BPFE. Yogyakarta

Boediono, (1981). Teori Pertumbuhan Ekonomi, BPFE UGM, Yoyakarta

BPS Statistik Kabupaten Lampung Timur (2017) 
Fahlevi, M. F. \& Gunawan, E (2016) Analisis pengaruh infrastruktur ekonomi dan social capital terhadap PDRB di provinsi Aceh. Jurnal Ilmiah Mahasiswa (JIM) Ekonomi Pembangunan Fakultas Ekonomi dan Bisnis Unsyiah. 1(1),88-95

Frankel, J.A., (2005). Is trade good or bad for the environment? Sorting out the causality. Review of Economics and Statistics, 87(1), 85-91.

Ghozali. (2013). Aplikasi analisis multivariate dengan program SPSS. Universitas Diponogoro, Semarang

Jhingan. ML. (2007). Ekonomi pembangunan dan perencanaan, Edisi Jakarta: PT. Raja Grafindo Persada.

Lonni, Kaswani, T., \& Uppun P. (2009) Pengaruh kualitas sumber daya manusia terhadap pertumbuhan ekonomi di kabupaten Mamasa. WorkingPaper

Ikhsan. 2004. Hubungan antara infrastruktur dengan pertumbuhan ekonomi dan pembangunan. LPEM, Jakarta.

Mulyadi. S, (2008). Ekonomi Sumber Daya Manusia, Rajawali Pers, Jakarta

Todaro, M.P., (1995). Ekonomi untuk negara berkembang; suatu pengaturan tentang prinsipprinsip, masalah dan kebijakan dan pembangunan; Edisi Ketiga. Bumi Aksara, Jakarta

Hermanto, S (2006). Dampak Pertumbuhan Ekonomi Terhadap Penurunan Jumlah Penduduk Miskin, IPB and Brighten Institute.

Robby., S. (2006). Hubungan antara Pembangunan Manusia dengan Pertumbuhan Ekonomi. Jakarta

Sibarani, M. H. M. (2002). Kontribusi infrastruktur terhadap pertumbuhan ekonomi indonesia [Tesis]. Program Pascasarjana Magister Sains Universitas Indonesia, Jakarta

Sumarsono, Sonny. (2003). Ekonomi manajemen sumber daya manusia dan ketenagakerjaan, Penerbit Graha Ilmu, Yogyakarta.

Sukirno. S., (1985). Beberapa aspek dalam persoalan pembangunan daerah, LP-FEUI, Jakarta.

Widarjono, A. (2013). Ekonometrika: Pengantar dan aplikasinya, Ekonosia, Jakarta. 